Jingyi Wang. Determining the structure and content of the formation of the readiness of future teachers of music for vocal and pedagogical activities in higher education institutions in Chinawang Jin. Journal of Education, Health and Sport. 2020;10(8):614622. eISSN 2391-8306. DOI http://dx.doi.org/10.12775/JEHS.2020.10.08.073

https://apcz.umk.pl/czasopisma/index.php/JEHS/article/view/JEHS.2020.10.08.073

https://zenodo.org/record/4670408

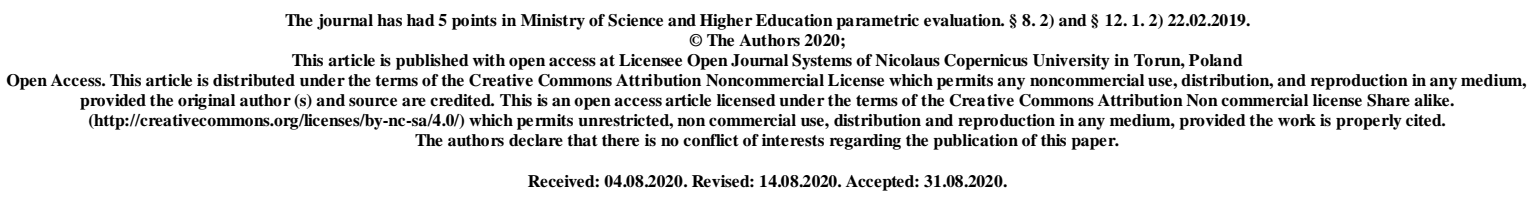

UDC 378.147: 372

DETERMINING THE STRUCTURE AND CONTENT OF THE FORMATION OF

THE READINESS OF FUTURE TEACHERS OF MUSIC FOR VOCAL AND

PEDAGOGICAL ACTIVITIES IN HIGHER EDUCATION INSTITUTIONS IN

CHINAWANG JINGYI

\author{
Wang Jingyi \\ H. S. Skovoroda Kharkiv National Pedagogical University, Ukraine \\ 2564610@qq.com
}

\begin{abstract}
The article defines the essence of the concept «readiness of future teachers of music art for vocal and pedagogical activities» and proposes its structure. The author substantiates the components of readiness of future music teachers for vocal and pedagogical: motivational and value (focus on music and aesthetic education), content-target (systematization of knowledge, skills and abilities that meet the purpose), operational (set of knowledge and skills of students), which contribute to the formation of cognitive-value, emotional and artistic attitude to the art of music), productive-reflective (self-esteem and reflection).

Keywords: teacher; music; professional activity; vocal and pedagogical activity; preparation; readiness; institution of higher education; China.
\end{abstract}




\section{Relevance of the research}

The transformational processes that are currently taking place in the world are aimed at reviving national traditions, addressing the cultural and spiritual values of peoples and nations. These processes have not escaped the Ukrainian education system, where one of the leading tasks is the further humanization of the educational environment, which is based, according to the Law on Education, on «respect for the cultural values of the Ukrainian people, its historical and cultural heritage and traditions». In view of this, the National Strategy for Education Development in Ukraine until 2020, in the section «Main objectives of the National Strategy for Education Development» states that «for the development of modern quality education it is advisable to use the significant potential of art as a means of forming and developing ethical principles and ideals for the spiritual development of the individual. In this regard, a special role belongs to future teachers who have not only a high level of knowledge, skills and abilities in the field of music, but also a willingness to carry out vocal and pedagogical activities aimed at developing the student's personality, abilities, creative activity, thinking, harmonization». This problem is relevant for both Ukraine and China. One of the main tasks facing the modern teacher of music in both educational systems is that he must ensure the formation of spiritual, aesthetic, creative potential of the young generation of society.

\section{Analysis of previous research}

Vocal art is an important component of national and world musical heritage. The specifics of vocal training of future music teachers involves not only the acquisition of vocal and methodological competence, knowledge in the field of vocal art, professional skills in reproducing the vocal and artistic image, but also a constant desire to study world music heritage and maintain original national traditions of vocal performance. The analysis of scientific and pedagogical literature showed that vocal issues in the context of training future music teachers were studied by scientists of Ukraine and China: requirements for vocal training of modern music teachers were developed by L. Vasylenko, O. Marufenko, L. Totska, Y. Yutsevich and others; Gu Yu Mei, Xu Ding Chung, Wang Lei, Wei Limin, Gu Yu Mei, Jin Nan, Chen Ding, Zhao Wenfang, and others paid attention to various aspects of vocal music performance; methods of vocal training are presented in the works of $\mathrm{V}$. Antonyuk, N. Grebenyuk, Shen Xian, Yu Ten Gan, Yang Hong Nian and others; The specifics of the vocal and choral activity of a music teacher are covered in the works of G. Bolgarsky, A. Kozyr, L. Kunenko, O. Khyzhna. 
However, despite the importance of scientific achievements in the field of vocal and pedagogical education, the problem of readiness of future music teachers for vocal and pedagogical activities in higher education institutions in China remains undeveloped.

\section{Presenting main material}

Based on the provisions of Chinese scholars, the formation of the readiness of future music teachers for vocal and pedagogical activities, given its features, it is advisable to implement and define as a set of vocal and pedagogical requirements for the training of future teachers. We emphasize that a similar approach in shaping the readiness of future music teachers for vocal and pedagogical activities is followed by Ukrainian scientists.

Today, the rich Chinese experience allows to systematize and structure, based on the theory of activity, the basic requirements for a teacher who is capable of self-development and self-improvement in the process of professional activity.

According to scientist Qiao Chun [5], the organization of the educational process, especially at the Faculty of Arts, should focus its vector of development on the formation of the future teacher, armed not only with general pedagogical and psychological knowledge, but also a system of knowledge, skills and abilities in music. This amount of competencies should help students in further professional activities to develop students' cognitive and value attitude to music, vocal activities.

The above ideas are developed by Tian Xusheng [8], who notes that the set of knowledge in the field of vocal art is a set of musical values, and the set of knowledge and skills in the theory and practice of singing, special and general pedagogy, psychology, are the main content of vocal readiness. Pedagogical activity, and is also an important component of professional activity of future teachers. The scientist proves in his scientific works that the above not only contributes to the successful preparation for this type of activity, but also creates opportunities for mastering other types of musical activities.

This view is supported by Luo Yanji [9], according to which a certain amount of defined competencies is a factor in raising the level of culture, which develops the material and spiritual component of Chinese society.

On the basis of dictionary, reference literature, as well as the analysis of scientific achievements of scientists, we define the essence of the concept of «readiness of future teachers of music for vocal and pedagogical activities».

In the dictionary, the term «readiness» has two meanings: «agreement to do something» and «a position that assumes that everything is ready to do anything» [3, p.137]. 
Interpretation of this word in the psychological and pedagogical aspect allows us to understand it as a state in which a person has the ability to move to a new stage of life, or mastering a new activity for him [1, p. 68].

In practice, it is quite difficult to separate the «formation of readiness for a particular activity in the process of special training» from the problems of readiness of the individual for life in general. On the contrary, in works on formation of readiness of the person for professional activity it is noted that special preparation creates favorable conditions for successful performance of any kind of activity.

Studies of Chinese scientists in the field of vocal pedagogy confirm the above and prove in their work that vocal activity significantly affects the development of intelligence, emotionality, aesthetic sense, spirituality, develops a positive attitude to the world, ie, aimed at self-development.

An analysis of the scientific work of Chinese researchers suggests that readiness is a dynamic formation, carried out in the direction from the general to the specific, and at the same time contributes to the solution of problems in the field of music. It should also be noted that in the works of scientists it is valuable to believe that the readiness for professional activity is intended to solve the main tasks of pedagogy: training, education and development of «individual-humanistic» personality.

Readiness, according to Qiao Chun [7], is not a set of knowledge in certain sciences, but, according to many scholars, a phased system of entry of the individual into the world, which implies the presence and development of positive qualities inherent in man. In the most general form in readiness for life, according to Guo Xiaoming [12, p. 30], a person must have and develop such qualities as: intelligence; emotionality; self-confidence and self-perception; resistance to stress; independence and autonomy; positive attitude to the world and perception of others; motivation, self-actualization and self-improvement.

Concretizing the interpretation of the essence of the concept of readiness, scientists in their research distinguish between practical and psychological readiness, socio-mental readiness for mental and physical activity, readiness associated with the formation of communication skills and more.

According to Guo Biao and Xu Jing [11], revealing the theoretical foundations of the phenomenon of «professional readiness» in their study, scientists note that the most important in this process is the acquisition of knowledge, skills and abilities in accordance with future professional activities. 
We should also pay attention to the fact that in dictionaries the essence of the concept of «readiness» is a certain mental state, which is understood as the purposefulness of the individual to certain views, motives, feelings and intellectual qualities, knowledge, skills, attitudes, moods. Certain types of behavior» [1]; «A multifaceted phenomenon, which includes not only psychological, but the corresponding psychological, physiological and physical characteristics» [3]. In view of the above, in our opinion, these interpretations are taken into account, as the needs of vocal and pedagogical activities are based on the provisions and concepts of physiology and neurophysiology.

It should be noted that readiness, as a condition for successful performance, ensures its self-realization in the preparation and solution of certain tasks based on their own experience. The basis for the successful performance of any activity, including vocal and pedagogical, are professional qualities that contribute to the understanding of personal readiness.

A Chinese scholar like Xu Jin [10] also singles out such a leading activity. This type of activity, according to the researcher, leads to the transition of the individual to a new level of self-knowledge, the establishment of the internal position of the individual. Chinese researchers identify the following aspects of readiness to learn: intellectual, emotional, social. As for mental activity, it is characterized by the ability to differentiated perception, analytical thinking, involuntary attention and memory, and so on. Scientists associate emotional maturity with emotional stability and lack of impulsiveness. Social maturity is understood as the need for communication, the ability to obey the common interests and accepted conditions, the ability to take on the social role necessary in the context of university education.

It should be noted that Ukrainian scholars in this regard are convinced that a person's readiness for professional activity should be based on individual needs, innate inclinations that do not depend on external conditions and upbringing.

The analysis of the scientific literature, primarily in Chinese scientific thought, gives grounds to argue that the main types of readiness of the individual in education should include:

1) the formation of certain skills and abilities necessary for learning;

2) personal readiness;

3) intellectual readiness;

4) motivational readiness;

5) emotional and volitional readiness;

6) communication readiness. 
The reference literature prescribes such important characteristics for structuring readiness for activity as situational and stable readiness [3].

According to some scholars [4], the essence of the concept of «readiness» is considered as «competence». Researchers identify several types of professional competence:

1) special competence, which provides a high level of mastery of professional activities and the ability to further professional development;

2) social competence, which requires mastering the skills of joint professional activity, cooperation, communication and professional compliance;

3) personal competence, which is associated with mastering the ways of personal selfexpression and self-development;

4) individual competence, which means mastering the methods of personal selfexpression and self-development of the individual within the profession, readiness for professional and personal development, self-organization and self-rehabilitation.

We also agree with these provisions and note that in preparation for vocal and pedagogical activities, the teacher will pass on their knowledge, skills and abilities to the student, who will form their key competencies, but taking into account the established competencies of the teacher.

Of course, the relationship between practical and theoretical readiness determines the professionalism of the specialist, in addition, the competence of the teacher should be considered as a unity of general competence, competence in science, based on established psychological and pedagogical competence in music and pedagogical activities [6].

Khan Zhimin develops the ideas presented above in his works [10, p. 19]. The scientist believes that the obligatory component of professional competence should be the skills and abilities of practical musical activity, including vocal and pedagogical activities. Problems of professional readiness of teachers are revealed in the works of scientists, in which researchers determine the readiness of the regulator of pedagogical activity, the basis of its effectiveness, determine the main qualities of readiness of future teachers such as: positive attitude to the profession, temperament, abilities, knowledge, skills and abilities. Among the professionally important qualities, scientists have included memory and thinking.

According to Gen Jinghen [2], pedagogical readiness is a kind of stock of knowledge, skills and abilities that a person has at the time of entering a new type of activity. Continuing to further develop his views on research in the context of professional readiness, Gen Jingheng [2] is convinced that professional readiness for teaching is defined as a set of professional requirements for teachers. We also support the opinion of the Chinese scientist 
and are convinced that the performance of professional functions requires national stability, mental tact and endurance, pedagogical thinking, which allows you to analyze your own activities.

Summarizing the works, which reveal the problem of readiness of future music teachers for vocal and pedagogical activities, we define, on the one hand, psychological, psychophysiological and physical readiness, on the other - theoretical and practical, as the basis of professionalism.

Thus, based on the analysis, the components of the readiness of future teachers of music to vocal and pedagogical are: motivational and value (focus on music and aesthetic education), content-target (systematization of knowledge, skills and abilities that meet the purpose), operational (a set of knowledge and skills of students who contribute to the formation of cognitive-value, emotional and artistic attitude to the art of music), productivereflective (self-esteem and reflection).

The content of professional readiness of future teachers of music art for vocal and pedagogical activity is united by us into three main complexes (professional profile): general civic qualities; qualities that determine the specifics of the teaching profession, special knowledge, skills and abilities. The very essence of the concept of «professiogram» will be interpreted in our study as pedagogical abilities, such as didactic, academic, communicative, imagination, ability to distribute attention and so on.

It should also be noted that a necessary condition for the formation of readiness for professional activity is professional training, which is defined as the result of mastering pedagogical knowledge, skills and abilities, personality traits and abilities necessary to perform professional functions.

The analysis of the scientific literature gives grounds to assert that the studied readiness can be considered as a holistic structured system of activities for the development of cognitive interests of students who are provided with the necessary personality qualities.

\section{Conclusions}

The essence of the concept of «readiness of future teachers of music for vocal and pedagogical activities» is considered as a complex personal and activity education, which provides students with a system of theoretical and practical knowledge, skills and abilities that contribute to spiritual and emotional (emotional and value). Artistic and creative development of the student's personality through his perception of vocal works and the formation of the foundations of vocal and performing skills. 
The structure of readiness of future teachers of music art for vocal and pedagogical is determined as a set of such components: motivational and value, the main purpose of which is the focus on music and aesthetic education; content-target, which involves the systematization of knowledge, skills and abilities that meet the purpose of the activity; operational, which combines a set of knowledge and skills of students on the development of the basics of vocal skills of students and the formation of cognitive-value, emotional and artistic attitude to the art of music; effective-reflective, aimed at adequate assessment of themselves as a teacher of music and the results of vocal and pedagogical activities. The content of preparation of future teachers of music art for vocal and pedagogical activity aims to form general civic qualities; qualities that determine the specifics of the teaching profession, special knowledge, skills and abilities.

We see prospects for further explorations in the implementation of the experience of professional training of future music teachers for vocal and pedagogical activities in higher education institutions of Ukraine.

\section{References:}

1. Dictionary-reference book on pedagogy and psychology of higher school / [prepared. N.E. Gerasimov and others]. Cherkasy: ChNU, 2010. 212 p.

2. Gen Jinghen. The system of vocal skills as a basis for professional training of future music teachers. Scientific journal of the National Pedagogical University named after M.P. Drahomanov. Series: Theory and methods of art education. 2014. 6 (21): 68-71.

3. Large explanatory dictionary of the modern Ukrainian language / incl. and goal. ed. W. T. Busel. K .: Irpin: VTF «Perun», 2004. 1440 p.

4. Mikhaskova M.A. Formation of professional competence of the future music teacher: author's ref. dis. ... cand. ped. science: special. 13.00.02. Kyiv, 2007. 19 p.

5. 乔爱玲, 勇于开拓善于创新一地方院校音乐教育人才 培养模式新 探 $[\mathrm{J}$ ]，艺术教育，2011(06):49 [Qiao Ailing. Brave in pioneering and good at innovation. A new exploration of the talent training model of music education in local colleges. Art Education. 2011(06):49].

6. 卢斌玉,朱咏北.改革开放以来我国高师音乐教师教育专业课程设置研究概 况.音乐创作, 2016(07):191-194 [Lu Binyu, Zhu Yongbei. A Survey of the Curriculum Setting of Music Teacher Education in Higher Normal Schools since the Reform and Opening Up. Music Creation, 2016(07):191-194]. 
7. 王毅.试谈校园培养戏曲受众的意义.教书育人,2007(SA):104-105 [Wang Yi. On the significance of cultivating opera audiences on campus. Teaching and Education. 2007(SA): 104-105].

8. 田许生.高等院校音乐教育专业钢琴教学的研究.成功(教育),2013(18):45

[Tian Xusheng. Research on piano teaching of music education majors in colleges and universities. Success (Education). 2013(18): 45].

9. 罗艳洁.音乐无国界——浅谈大学音乐教育作用.留学生,2006(05):55-57

[Luo Yanjie. Music Without Borders-On the Role of University Music Education. International Students. 2006(05):55-57].

10. 许靖.重温经典体味高雅教育部推出2005年普通高等学校开展普 及高雅艺术活动.中国音乐育,2005(11):4-5 [Xu Jing. Revisit the classics and appreciate the elegance-the Ministry of Education launched the popularization of high art activities in ordinary colleges and universities in 2005. Chinese Music Education. 2005(11): 4-5].

11. 郭彪,许静.实施音乐类卓越艺术人才

教育培养计划的必要性分析. 北京教育(高教), 2015(Z1):109-110 [Guo Biao, Xu Jing. The Necessity Analysis of Implementing the Education and Training Plan for Outstanding Music Talents. Beijing Education (Higher Education). 2015(Z1): 109-110].

12. 郭彪,赵塔里木,魏兵兵.教育生态学视角下的高等音乐教育分析.中国大学 教学,2015(10):29-35 [Guo Biao, Zhao Tarim, Wei Bingbing. Analysis of Higher Music Education from the Perspective of Educational Ecology. China University Teaching, 2015(10): 29-35]. 